\title{
Gauss の法則の積分形での導出について
}

\author{
田原裕基
}

2020/04/15

Abstract

電磁気学ノート 3

\section{1 序論}

前回は電場という概念を導入した。今回はその電場を制限する法則の一つとして 積分形で Gauss の法則を導出する。

\section{2 積分形の Gauss の法則}

\section{1 電気力線}

前回導入した電場 $\boldsymbol{E}$ (の大きさ) を視覚化しようとして用いられたのが電気力線で ある。この密度は電荷に近づけば近づくほど大きくなり、離れれば離れるほど小 さくなる。これは $\boldsymbol{E} \sim r^{-2}$ であるということからである。ここで一般に $S \sim r^{2}$ であることから、 $(\boldsymbol{E} \cdot S) \sim 1$ が示唆される。

\section{2 閉曲面と交わる電気力線の本数の一定性}

そこで、ある電荷 $q$ の周りを任意の閉曲面 $S$ で囲い、その面に交わった電気力線 を数え上げると、電荷と近いところでは電気力線の密度が大きい代わりに面積そ のものが小さく、逆に遠いところでは面積が大きい代わりに電気力線の密度が小 さいというようになり、ある一つの電荷から定まった本数の電気力線がでると考 えると、その数え上げる数は一定となるはずである。微小面積 $\mathrm{d} S$ あたりの交差 力線は、電気力線が電場を表すものであることから $\boldsymbol{E} \cdot \boldsymbol{n}$ と表せるため、この主 張は

$$
\oint_{S} \boldsymbol{E} \cdot \boldsymbol{n} \mathrm{d} S=\text { 一定 }
$$

と記述できる。 


\section{3 具体的な定数}

これが任意の閉曲面で成り立つため、例えば $q$ を中心とする半径 $r$ の球面 $S$ で考 えると、 $\forall \boldsymbol{r} \in S, \boldsymbol{E} \perp S \wedge|\boldsymbol{E}|=k \frac{q}{r^{2}}$ でかつ $S=4 \pi r^{2}$ であるから

$$
\oint_{S} \boldsymbol{E} \cdot \boldsymbol{n} \mathrm{d} S=|\boldsymbol{E}| \cdot S=k \frac{q}{r^{2}} \cdot 4 \pi r^{2}=4 \pi q k
$$

となる。

\section{4 積分形の Gauss の法則}

上を点電荷だけでなく電荷一般に適用したのが以下の式で、これを(積分形の)Gauss の法則という。

$$
\oint_{S=\partial V} \boldsymbol{E} \cdot \boldsymbol{n} \mathrm{d} S=4 \pi k \int_{V} \rho \mathrm{d} V
$$

\section{3 展望}

今回導出した積分形の Gauss の法則はいわば電場の保存則である。冬休みに EMAN で学んだときには難なく受け入れられたが、よくよく考えると思考に大きな飛躍 があるので、それをいかに論理立てて埋めていくかで時間がかかった。この形で あると、幾何的に単純で対称性のある電荷分布においてはそれの生成する電場の 全体的な計算がしやすいが、きれいな分布ではないときの各点の電場を求めるの には向かないため、次回はこの法則を微分形式で記述したいと思う。

\section{References}

[1] 広江克彦, EMAN の電磁気学, eman-physics.net/electromag/contents.html

[2] 高橋和孝, 電磁気学基礎, 2019.

[3] システム奮闘記:その 105, http://www.osssme.com/doc/funto105-no80.html

[4] 田原裕基, 電場概念の導入について, 2020. 